Institute of

Public Finance

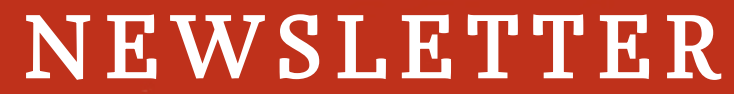

AN OCCASIONAL PUBLICATION OF THE INSTITUTE OF PUBLIC FINANCE

\title{
Financial and Tax Effects of Professional Athlete Transfer
}

\author{
DANIJELA KULIŠ Institute of Public Finance \\ JOSIP FRANIĆ Institute of Public Finance
}

\begin{abstract}
I INTRODUCTION
Public interest in sports is focused not only on sporting competitions and results, but equal; if not closer attention is paid to off-the-field events. The financial operations of sports clubs, non-transparency in granting subsidies from public sources, players' revenues and transfer fees, tax liabilities and unsettled liabilities to creditors are the favourite topics of sports news. Due to omnipresent commercialisation, sport has become an important segment of economy. Football, being one of the highly professionalised sports in the world and Croatia, has also become a lucrative entrepreneurial activity.
\end{abstract}

Given that sports in the Republic of Croatia ${ }^{\mathrm{I}}$ are for the most part financed from public (budgetary) sources, the public interest and inquiries about the business performance of sports clubs receiving the largest amounts of public funds are understandable. According to the Sports Act (SA), "sporting activities are of special interest to the Republic of Croatia" ${ }^{2}$, and the Constitution ${ }^{3}$ explicitly provides for the state's duty to "encourage and support care for physical culture and sports." Most legal entities in sports are organised as associations. At end-February 2013, there were 16,453 sports associations in the Register of Associations, accounting for $34 \%$ of all associations in the Republic of Croatia (RC). Of this, 2,776 were football clubs. The Associations Act as the general law and the Sports Act as a special law regulate the general issues of the establishment, organisation, legal status, regippation and termination of sports associations and all of their organisational forms. The Sports Act provides that sports clubs for competition can also be established as companies, i.e. that they can be obligatorily or voluntarily transformed from an association into a sport joint stock company, in which case they become subject to the Company Act.

Most football clubs in Croatia are civic organisations established in accordance with the Associations Act, whereas only four clubs are sport joint stock companies (HNK Hajduk, HNK Cibalia, NK Ippa 196I and HNK Rijeka)4, established mainly pursuant to the Sports Act provisions on obligatory transformation. However, participation in the Croatian First Football League contests is not only a

\footnotetext{
${ }^{\mathrm{I}}$ The Institute of Public Finance in 2012 made a study for the purposes of the Ministry of Science, Education and Sports (MSES) entitled "Sports Financing in the Republic of Croatia - a comparison with the European Union", some parts of which have been incorporated into this article. The project was led by Danijela Kuliš and Vesna Lendić Kasalo. The full text of the study is available on the MSES's website at: http:/ / public.mzos.hr/Default.aspx?sec=2379

${ }^{2}$ Art. I, para. (2) of the SA.

${ }^{3}$ Art. 69 .

${ }^{4}$ Also under a transformation process are NK Osijek and HNK Šibenik. For more details, see these clubs' official websites.
} 
sporting but also a commercial activity. While associations operate on the non-profitability principle, generating profit is a basic characteristic of economic activities.

Part two of the paper deals with the legal organisation of professional sports clubs in the RC and the prescribed financial monitoring and reporting systems. The organisational form of a legal entity also determines its rules of operation, financial reporting and taxation, as well as its responsibility for financial performance. The third part discusses taxation, especially of football player transfers. High transfer fees in football show that football, too, is ruled by the law of demand and supply. Also discussed is the tax status of the sports associations' revenues. Do transfer fees have the same tax treatment as the comparable transactions and revenues of other entities of equal legal status with respect to profit, income and value added taxes? The fourth and fifth parts outline the structure and operation of football clubs, as well as the rules governing transfers in some EU member states, where, as in the RC, the tax status of a club depends on its organisation.

\section{ORGANISATION OF PROFESSIONAL SPORTS GLUBS IN THE REPUBLIC OF GROATIA AND FINANCIAL REPORTING}

According to the Sports Act, the "activity of participating" in sporting competitions can be performed by natural and legal persons. Irrespective of their legal form (an association for competition or a joint stock company), sports clubs can have professional ${ }^{5}$ or amateur status. Irrespective of their organisation, professional sports clubs must be entered into the Register of Professional Sports Clubs, kept by the MSES. The Register is in electronic form and is public, so that everybody has a right to access the data without proving their legal interest, and to require a certificate from the Register. According to the MSES' website data (of I February 2013), there are 15 registered professional clubs in football, 5 in basketball and only one in handball ${ }^{6}$, while 4 football clubs and one basketball club have lost that status.

The Committee on Professional Sports Clubs, an expert body within the MSES monitoring the activities of professional sports clubs, maintains records of the documentation to be obligatorily submitted by clubs. The Committee gives approval for the selection of an auditor who determines whether conditions have been met for instituting bankruptcy proceedings in a professional sports club or for its obligatory transformation into a sport joint stock company. Under the Regulations on the Scope and Mode of Operation of the Committee on Professional Sports Clubs, the Committee has powers involving a direct influence on the financial operations of professional sports clubs.

Specifically, professional sports clubs are obliged to submit to the Committee on an annual basis an income statement, a report on registered senior team athletes, annual financial and audit reports, a business plan for the following business year, a report on club members and members of the bodies of clubs. The national federation regulates the consequences of the non-compliance with these obligations by a general by-law.

The Sports Act regulates in some detail the establishment and operation of sports clubs - sport joint stock companies (SJSCs) to which the Companies Act and other legislation governing joint stock companies are subsidiarily applied. SJSCs can be established as new joint stock companies or transformed from sports clubs or associations for competition (regardless of whether they have professional or amateur status), either voluntarily or obligatorily. Obligatory transformation occurs in the case of a sports club in football, basketball or handball entered into the Register, if it is established during the audit that conditions have been met for instituting bankruptcy proceedings pursuant to special regulations ${ }^{7}$.

\footnotetext{
${ }^{5}$ Professional status is held by a sports club founded to perform the sporting activity of participating in sporting competitions, if more than 50\% of registered athletes in senior competition (from a list maintained by the relevant national sports federation) have signed professional contracts or employment contracts with that club or if they perform an independent sporting activity of participating in sporting competitions, or if the sports club meets the professional status requirements in accordance with the rules of the relevant national sports federation.

${ }^{6}$ This means that only I\% of all football clubs in the RC have professional status. As suggested by the Croatian Football Federation's website data, I,42O football clubs with 650 professional players are registered in the competition system in the RC (of a total of II8,316 registered players, 44,I62 are in senior competition).

${ }^{7}$ For more about the transformation, see Vuković (2OII).
} 
Are there conditions in Croatia for a successful transformation of football clubs into sport joint stock companies? The main prerequisite for that in best European leagues was a sufficient number of interested market participants (fans buying tickets and club memorabilia, sponsors, TV stations paying for the right to broadcast matches, and private investors) willing and able to allocate funds for the activities of a particular club. There are no accurate data on business demand for football in Croatia that could provide adequate sources of funding for the clubs after their transformation. Are local communities, as the biggest donors but also creditors, interested in becoming the main shareholders of local football clubs, or is this expected from private entrepreneurs for whom this would be a profit opportunity, or even fans as small shareholders who make contributions in order to show how much they care for the survival of their favourite sports club?

The financial reporting systems for all non-profit organisations, including sports associations and institutions, are governed by the Regulation on Accounting for Non-profit Organisations ${ }^{8}$. The person responsible for the objectivity and reliability of financial reports is the legal representative, i.e. head of an association or institution. The reports are submitted to the State Audit Office and FINA ${ }^{9}$ for the purposes of the Ministry of Finance and the Croatian Bureau of Statistics, and are not publicly available. However, the enforcement of the Fiscal Responsibility Act and the Decree on the Drafting and Submission of a Statement of Fiscal Responsibility and a Report on the Application of Fiscal Rules is expected to have a major indirect effect on the supervision, primarily over the spending of funds for non-profit organisations partly financed from the state or local budgets. On the other hand, the annual audit reports of SJSCs are publicly accessible through the Register of Companies, and they show in a transparent manner both the revenues from transfers and tax liabilities.

\section{TAXATION IN SPORT - THE TAX STATUS OF PLAYER TRANSFER FEES}

The tax position of entities in sports depends on their legal form and objectives. The legislation rarely provides for a special tax position of sports entities, which rather depends on the legal status of such entities, which entails the application of adequate tax rules. Another criterion is also whether an entity is profit-oriented or not. In the case of a profit-making organisation, the applicable tax rules will be the same as those applied to any other business entity. However, if the organisation is not aimed at profit making, according to the Croatian legislation as well as most European legislations, it is entitled to certain tax benefits applicable to all other non-profit organisations as well.

Pursuant to effective regulations and the new Draft Associations Act which is currently under public consultations, sports clubs operating as associations, (non-profit legal entities) may perform incomeearning activities in accordance with their Statutes and special regulations governing the conditions for the performance of such activities. However, being a non-profit association, such an entity may not perform any activity aimed at making profit for the benefit of its members or a third person. The realised surplus of revenues over expenditures must be exclusively used for the performance and promotion of the activities laid down by the Statute.

While, pursuant to the Corporate Income Tax Act ${ }^{\mathrm{IO}}$, certain non-profit legal entities, including sports clubs, sports associations and federations, are not subject to the corporate income tax, there is an

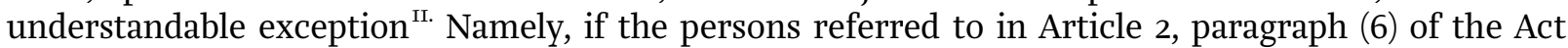
perform a commercial activity, which, if not taxed, would enable the persons to obtain unjustified privileges in the market, the Tax Administration is authorised, at its own initiative or at the proposal of other taxpayers or another interested party, to determine, by a ruling, that such persons are liable to pay corporate income tax for that activity. Hence, where a sports association performs a commercial activity as described above, its income may be taxed in accordance with the ruling of a competent Tax Administration.

Similarly, under particular conditions and pursuant to a ruling of the Tax Administration, associations may be subject to VAT for the delivery of goods and services. However, as the relevant data are

\footnotetext{
${ }^{8}$ Articles 65-72.

${ }^{9}$ FINA (Financial Agency) is the leading Croatian institution in the field of financial mediation providing financial and adminippative services to natural and legal persons.

${ }^{\text {Io }}$ Art. 2, para. (6).

${ }^{\text {II }}$ Art. 2, para. (7).
} 
protected by tax secrecy provisions, it was impossible to obtain information, for the purposes of this article, on the number of football clubs registered in the VAT system, or the number of clubs subject to the corporate income tax.

The issue of income from the transfers of athletes from one club to another is very often raised in connection with football players and clubs, regardless of whether they operate as associations or SJSCs. How are transfers revenues presented in the financial statements of Croatian professional sports clubs operating as associations, and are they subject to taxation?

Unfortunately, the financial statements of non-profit organisations are not publicly disclosed, and it is therefore impossible to establish how and under what items these revenues are booked. In the annual financial statement of the SJSC Hajduk ${ }^{\mathrm{I}}$ transfer revenues are booked under the "sales revenues" item, with the transfer revenues accounting for $70 \%$ of total revenues in 2011.

The status of transfers can be viewed from the perspective of the corporate income tax and VAT, when the liability is on the club, or from the perspective of personal income tax, in the case of players liable for tax on income from transactions, or managers liable for tax on income from commissions on transfer fees.

\section{Transfers of the FC Dinamo players to foreign football clubs}

Article 67 of the General Tax Act (OG I27/OO, 86/OI and I5O/O2) prescribes the obligation of taxpayers and other persons to provide information to the tax authorities which are necessary for establishing the facts relevant to taxation.

The Tax Administration has required from the FC Dinamo all the necessary data and documentation related to player transfers. Pursuant to the concluded contracts, the tax liabilities depend on the manner of payment. Hence, if the contract stipulates that payments are to be made to a natural person, the provisions of the Personal Income Tax Act (OG 177/O4) will apply. On the other hand, if the contract stipulates that the payment is to be made to a legal entity, the taxation will be governed by the Corporate Income Tax (OG I77/O4, 90/O5 and 57/06.).

Available at: http://www.mfin.hr/hr/novosti/transferi-nogometas-a-nk-dinama-u-ppane-nogometne-klubove06-08-2007

In terms of the corporate income tax, profit is defined as the difference between revenues and expenditures. Is the compensation/fee for the sale (transfer) of a player the revenue that can at the end of the year result in the profit ${ }^{13}$ of the club which sold the player? Can such a club be a non-profit association performing a commercial activity? According to regulations, it definitely can, but according to economic criteria, the sale of a player is by no means a non-profit but a commercial activity. Football clubs and the players enter into contracts of limited duration. Should a player bound by a contract wish to change clubs before the expiration of the contract, the clubs can negotiate the fee to be paid to the former club by the new club to which the player moves. This constitutes a business relationship between the two clubs. Therefore, (pursuant to Article 2 of the Corporate Income Tax Act), the Tax Administration may, at its own initiative or at the proposal of other taxpayers or interested parties, due to the violation of the tax equity and neutrality principles determine by a ruling that it represents a commercial activity. According to the Sports Act, (football) clubs can be civic associations, but considering the provisions of the Corporate Income Tax, each particular case must be closely examined in order to determine whether the activity concerned is profitable or nonprofitable.

Sports clubs in Croatia, registered as sports associations, are mainly not subject to corporate income tax, but they may be registered in the VAT system. A sports club's revenues (e.g. from sponsors, for marketing services or broadcasting rights) may exceed HRK 230,00o kuna, which is the current VAT registration threshold, and such a club becomes legally subject to VAT registration.

\footnotetext{
${ }^{12}$ Available at: https://sudreg.pravosudje.hr/registar/f?p=I5O:28:862I24408483223::NO:28:P28_SBT_MBS:060250783

${ }^{13}$ In some EU member states (e.g. Italy or UK) these revenues are subject to the corporate income tax, as suggested by the FATF and UEFA Recommendations. In these countries, professional clubs are also required to be registered as firms or joint stock companies.
} 
In order to determine the tax treatment of player transfers in football (Jelić, 20IO), it is necessary to analyse the provisions of the VAT Act in the part defining the object of taxation (in our case: services) and the status of the entrepreneur, and establish the real form of the relevant transaction.

According to the VAT Act, subject to tax are all deliveries of goods and services in the country made for a consideration by an entrepreneur (a taxpayer) within his/her entrepreneurial activity. The general concept of a service as the object of taxation (Article 4, para. (I) of the Act) involves that "services rendered are all services not considered as delivered goods". However, the Act provides a very detailed and broad definition of services (e.g. handing over of goods for use - rent or lease, transferring property rights, e.g. the transfer and safeguarding of patent rights, inventor's rights, industrial property and similar rights, the suffering of or refraining from an action, etc). It follows that the objects of taxation also include transfers of players, i.e. fees for the rendered player transfer services, provided that such services have been rendered by an entrepreneur within its business activity. In order to be considered entrepreneur in terms of the VAT Act, a natural or legal person does not have to be considered entrepreneur according to other laws, and it is irrelevant whether the person is an association, institution or a company. The only thing that matters is that the person generates income, because VAT is a tax on the turnover of goods and services and not on the results of a commercial activity. Football clubs, just like other sports clubs, make deliveries of goods and services (they sell tickets and club memorabilia, receive fees for player transfers and space rentals, etc.), which all makes them entrepreneurs. As of I January next year, they will also be taxpayers if they made taxable deliveries of goods and services in the previous year in the value exceeding HRK 230,00O.

The legal form of player transfers is also shown in the following opinion of the Tax Administration ${ }^{\mathrm{I4}}$ : Where a sports club subject to VAT allows a player to move to another club it waives the rights with respect to this player and receives compensation for that. Pursuant to Article 4 of the VAT Act, the waiver of rights represents a service which is the object of taxation. Accordingly, where one contracting party waives its contractual position against a consideration paid by the other party, this obviously represents a service (in terms of the VAT Act).

All the above said relates to player transfers in Croatia. If a transfer service is viewed from the perspective of a general service, the place of taxation is in the country (the location of the service provider). Where a domestic club pays a transfer fee to a foreign club, the assessment and payment of VAT is carried out in the country where the foreign sports club has its seat. From the perspective of the service recipient, the taxpayer in foreign transactions is the foreign entrepreneur.

Do sports clubs subject to VAT charge value added tax on fees for transfers within Croatia?

Since the taxation of player transfers, i.e. transfer fees as the objects of taxation, is not expressly stipulated, either in the Croatian VAT Act or in the EU VAT Directive, the question is how to proceed in practice. On the other hand, the content of such a transaction, as well as the relevant provisions and definitions of a service and an entrepreneur, or a taxpayer, definitely suggest that what we have here is a rendered service which is the object of taxation (Javor, 2007: II9).

The performance of sporting activities by natural persons is subject to the personal income tax, surtax on personal income tax and the payment of compulsory insurance contributions. Depending on the manner of performing their activities, such persons can be subject to tax on income from employment (employed persons and pensioners) or self-employment, or other income.

An athlete having a professional contract is considered to be in employment from which he/she receives income (a salary), which is subject to general taxation rules applicable to all other taxpayers. The employer is obliged, when paying salaries, to assess and pay the relevant contributions, as well as tax and surtax.

Pursuant to the Sports Act, natural persons in the sports system also include sport managers, who are authorised, according to the national federation rules, to mediate the transfers of athletes from one sports club to another, and are entitled to a share of revenues from such transactions.

${ }^{14}$ Opinion of the Tax Administration, Class 4IO-19/03-OI/384 of 27 February 2007. 
Despite not being explicitly stated as a type of income, natural persons' receipts from transfer fees are taxable, and the tax charged depends on the manner of performing the business activity (as employment or self-employment, or as a freelance activity).

\section{TRANSFERS OF ATHLETES IN THE EUROPE UNION}

The European Commission attaches great importance to athlete transfers. Its policy document "Developing the European Dimension in Sport" (European Commission, 2OII) emphasizes the EU mandate to support, coordinate and implement sport policy measures taken by Member States, while recognizing the need for a thorough review of transfers from both a legal and an economic point of view.

A study "The Economic and Legal Aspects of Transfers of Players" (European Commission, 20I3) has been published on the EU website, dealing with the legal, economic and social aspects of the transfer systems of most European sports clubs, especially in football and basketball.

The total amount of transfer fees paid for 18,300 football players in the EU during the 20Io/20II season was about EUR 3bn, while the fees for basketball players amounted to EUR 27m. In the period I995-2OII, the number of transfers more than tripled and the fees rose almost 7.5 times.

The legal framework for the transfer system is set up by umbrella sports organisations in order to ensure fair and uniform conditions for sporting competitions in accordance with the principles of equal winning opportunities for each participant and non-discrimination. Taking into account the specificities of individual sports, the EU legislation had an important influence on the development and definition of rules stimulating player mobility, whereas national legislations regulated all issues related to the organisation and operation of sports clubs, labour relationships and taxation. The rules introducing greater transparency in transfer-related transactions will facilitate the fight against abuse and improve overall management in football.

The study warns of an increase in competitive inequality (reduced competitiveness), at the levels of both the EU and member states, and of inadequate efficiency of current rules in preventing inequality in sports competitions.

It is therefore necessary to promote equal conditions for all sports clubs through a more equitable distribution of funding, limit excessive fees, strengthen the solidarity system and improve the management and transparency of transactions, as well as implement equitable dispute resolution mechanisms.

The EU Commission has recommended that inflated transfer fees should be subject to some kind of a fair play tax through which money would be reallocated among rich and less rich clubs and amateur sports organisations.

The financial power of transfers is concentrated on a small number of football clubs in Europe, supported by wealthy investors, while only $2 \%$ of total transfer fees go to lower league sports clubs. Hence, the financial power of a club strongly influences its competitiveness, and, consequently, the sports results.

Also emphasized is a need to promote co-operation with public authorities in setting up a legislative framework with clearly defined rules for the prevention of criminal activities (money laundering, tax fraud and evasion and match fixing) which is so common in sports.

\section{ORGANISATION OF FOOTBALL GLUBS IN SOME EUROPEAN GOUNTRIES}

The transformation of football clubs from non-profit organisations to market-oriented entities in top European leagues was taking place during the ig8os and ig9os. The top national league football has gradually turned into big business with increasing revenues. Changed conditions have posed new challenges (primarily the need for effective management and financial responsibility) which can hardly be responded to by the existing non-profit organisation model. Due to irresponsibility and a lack of professional expertise on the part of the management, many clubs accumulated debt during the I980s, and public sources of funds (mainly city budgets) were therefore perceived as a reliable 
solution and a way out of an untenable financial position. This prompted government authorities to prescribe, through a number of laws, the obligation to transform clubs into economic agents, completely independent of public sources of funding.

In Italy, a law of 1981 stipulated that professional clubs should be transformed into joint stock companies, and each profit was to be reinvested in sporting activities. During the I99os, the bans on dividend payment to stockholders and on investment of profits in other non-sporting activities were lifted, provided that 10\% of the profits were reinvested in football academies for junior players. In England, all first league clubs have been organised as corporations since 1982. In Spain, after the government had failed to impose financial discipline on sports clubs by the so-called Rehabilitation Plan, a Sports Act was introduced in I990, prescribing the obligatory transformation of professional football clubs into private business entities, specially designed for the sport (with the exception of the Athletic Bilbao, FC Barcelona, CA Osasuna and Real Madrid clubs, which were organised according to the so-called "ocios" model (one member - one vote, i.e. all club members have the right to vote).

Germany is specific in this respect, as sports clubs in that country can appear in four different legal forms. Since 1998, the clubs have been able to take some form of a company. However, instead of direct transformation, most clubs organised as associations have established corporations by contributing the entire enterprises, or the professional operations thereof as stakes.

The tax positions of sports clubs in both Croatia and EU member states are determined by their organisational forms. Thus, the applicable tax regulations provide a more favourable position to nonprofit organisations (in the form of income tax and profit tax exemptions, reduced rates or exemptions within the VAT system). When it comes to joint stock companies, the taxation rules are equal to those applied to other economic agents.

However, illegal activities related directly or indirectly to taxation (FATF, 2009.) pose a more serious problem. The growing economic importance of sports and globalisation (especially in football) have not only positive but also negative effects. Various cash flows and transactions, as well as a large number of participants increase the risks of illegal activities (money laundering, corruption, tax fraud or evasion, tax registration in countries with more favourable tax rates, and tax offenses). One of the risky transactions is also the transfer of players.

Despite its undisputable importance, the issue of illegal activities in sports from the tax perspective would require a separate and more detailed analysis, and is not the subject of this article. Nevertheless, the following conclusions can still be drawn.

\section{CONCLUSIONS}

\section{Status of professional sports clubs and transformation of associations into SJSCs}

Each professional sports club can choose a legal structure that best suits its business needs. However, regardless of its structure, a club may engage in a commercial activity that is subject to corporate income tax or VAT, which both lie within the competence of the Tax Administration.

It is questionable whether a sports club may be for the most part financed from public sources, while at the same time performing economic activities (e.g. sponsorship and advertising, transfers, ticket sale, TV broadcasting, etc.), without violating the principles of market competition and equality and fairness of the terms and conditions of sporting competitions.

Conditions should be created for a larger participation of market and self-financing activities in the financing of professional sports clubs (not only in football). This would also provide a basis for reallocating a portion of public funds to other target groups and sports activities within the local authorities' jurisdictions. This process requires massive efforts from all levels of authority, but also from the society as a whole, aimed primarily at the fight against corruption in sports organisations, match fixing and violence at sports events, in order to encourage the interest of the public, sponsors and private investors in sports. 


\section{Transparency of operation and financial reporting}

The financial reporting system of a professional sports club, regardless of its structure, should be transparent and should convey an objective and realistic picture of the club's financial position and operation. Given the marked differences in the annual financial statements between associations and joint stock companies, for the purpose of transparent monitoring of professional sports clubs, the uniform content of the financial statements should be laid down by a special regulation, in order to make them comparable and easy to monitor in a standard way. While the annual audit reports of sports joint stock companies are publicly available via the Register of Companies, the Ministry of Finance should, as soon as possible, harmonize the regulations on financial reporting of non-profit organisations, so that the financial reports of sports associations (subsidized by public sources - the budgets of local self-government units) submitted to the Ministry of Finance can also be publicly available. Tax payers have a right to know how their funds are spent, and such information should be provided in the Register of Non-profit Organisations and/or Register of Associations.

\section{Taxation of transfers}

Activities connected with player transfers, given the high revenues derived from them, can by no economic criteria be considered as non-profitable. In order to prevent the violation of the tax equity and neutrality principles, the Tax Administration should determine the existence of a commercial activity and to make a decision to that effect. According to the Sports Act, professional sports clubs can be civic associations. However, in view of the provisions of the Corporate Income Tax Act, each individual case should be examined in order to establish whether the activity performed is profitable or non-profitable, and, consequently whether there is a tax liability or not.

The taxation of player transfers, i.e. of the transfer fees as the objects of taxation has not been explicitly stipulated (either in the Croatian VAT Act or the EU VAT Directive). Nevertheless, the content of such transactions, under the relevant provisions and definitions of the terms 'service' and 'entrepreneur' (the taxpayer), clearly points to a service rendered as the object of taxation. The Ministry of Finance should confirm this fact by a clear statement and a precise legal definition and should act accordingly.

The Personal Income Tax precisely defines what income is and who the persons subject to this tax are. It is on the Tax Administration to properly collect the tax.

\section{Regulation of transfers}

FIFA $^{\text {I5 }}$ has established an online Transfer Matching System (TMS), a data exchange application that makes transfers of players quicker, smoother and more transparent. The system was introduced in early 2008 and is currently used in all 208 FIFA members and by over 4,600 clubs. Apart from providing a detailed insight into and enabling evaluation of contracts, the System must also include provisions on financial transactions, i.e. indicate the exact sources of funds and their subsequent allocation. For the proper execution of transfers, clubs are required to provide detailed data on themselves and players, on the type of transfer and on the payment (the payer's and payee's parent banks, the amount of fee and payment dates), in order to ensure greater transparency and to establish a unified transfer monitoring system to be implemented in a uniform way.

The website of the Croatian Football Federation ${ }^{16}$ offers access to the regulations governing transfers (Rules of Procedure of Intermediaries in Player Transfers, Licensed Intermediaries in Player Transfers and Terms and Conditions for Taking an Examination for a Licensed Intermediary in Player Transfers).

All the above said suggests that an adequate legislative framework and rules governing player transfers exist, but there is still a need for co-operation between the responsible government authorities (Ministry of Science, Education and Sport and Ministry of Finance) and the sporting

\footnotetext{
${ }^{15}$ Available at: [http://www.fifa.com/aboutfifa/organisation/footballgovernance/transfermatchingsystem.html].

${ }^{16}$ Available at: [http://www.hns-cff.hr/hns/propisi-hnsa/propisi].
} 
community in the implementation of legislation and a transparent performance of all activities, particularly those related to taxation. As the sporting activities of both amateur and professional football clubs are largely financed by Croatian taxpayers, what they should get in return is not just good sports results but also a "fair play" outside the sports fields.

\section{REFERENGES}

Ascari, G. and Gagnepain, P., 2006. Spanish Football. Journal of Sports Economics, 7(I), pp. 76-89.

Baroncelli, A. and Caruso, R., 20II. The Organization and Economics of Italian Serie A: a brief overall view. Rivista di diritto ed economia dello sport, 7(2), pp. 67-85.

Delloite, 2013. Football Money League. Manchester: Sports Business Group at Deloitte

Dremel, N., 20II. Poslovanje športske udruge. Računovodstvo, revizija i financije, (5), pp. 6o-7o.

European Commission, 20II. Developing the European Dimension in Sport. Available at: 〈http://ec.europa.eu/sport/news/communication-on-sport-adopted_en.htm〉.

European Commission, 2013. The Economic and Legal Aspects of Transfers of Players. Available at: http://ec.europa.eu/sport/library/documents/f-studies/study-transfers-final-rpt.pdf.

FATF, 2009. Money Laundering through the Football Sector. [pdf] Paris: The Financial Action Task Force. Available at: 〈http://www.fatf-gafi.org/media/fatf/documents/reports/ML\%2othrough\%20the\%2O Football\%2oSector.pdf $>$.

Friganović, M., 20Io. Oporezivanje transfera športaša u RH. Poslovni savjetnik, I5. I. 20IO. Available at: 〈http://www.poslovni-savjetnik.com/racunovodstvo-porezi/oporezivanje-transfera-sportasa-u-rh〉.

Gómez, S., Martí, C. i Opazo, M. 2008. The structural characteristic of Sport Organizations: Differentiation within Elite spanish professional Football club. Working paper [online] Available at: 〈http://www.iese.edu/research/pdfs/di-o75I-e.pdf〉.

IJF, 20I2. Projekt Financiranje sporta u Republici Hrvatskoj s usporednim prikazom financiranja u Europskoj uniji. Available at: 〈http:/ / public.mzos.hr/Default.aspx?sec=2379〉.

Ivkošić, M., 20Io. Pravni uppoj nogometnih klubova u Republici Hrvatskoj. Zbornik radova Pravnog fakulteta u Splitu, 47(2), pp. 359.-385.

Javor, Lj., 2007. PDV i naknade za prijelaz igrača. Računovodstvo, revizija i financije, (Io), pp. IIg.

Jelić, H., 20IO. Oporezivanje transfera nogometaša PDV-om. TaxFlash [online] Available at: 〈http://www.zgombic.hr/UserDocsImages/TaxFlash/TaxFlash_02_20Io.pdf〉.

Kelly, K., Lewis, R. i Mortimer, T.,R., 2012. In Football We Trust? International Journal of Business and Social Science, 3(8), pp. 243-254.

Klauški, T., 2007. Tko su neformalni vlasnici nogometnih klubova. Poslovni dnevnik, 7.I2.2007. Available at: 〈http://www.poslovni.hr/after5/tko-su-neformalni-vlasnici-nogometnih-klubova-63307〉.

Legge del 23 marzo I98I, n. 9I. Gazzetta Ufficiale del 27 marzo I98I, n. 86

Lončarić-Horvat, O., 20Io. Šport i porezno pravo. Pravo i porezi (5), pp. I6-I9.

Ministarstvo financija. Računovodstvo neprofitnih organizacija. Available at: 〈http://www.mfin.hr/hr/neprofitno-racunovodstvo〉.

Ministarstvo financija. Uputa o primjeni članka 7I. Uredbe o računovodstvu. Available at: <http://www.mfin.hr/adminmax/docs/Uputa\%200\%2Oprimjeni\%2Oclanka\%207I.\%20\%20Uredbe\%2 oo\%2oracunovodstvu\%2oneprofitnih\%20organizacija.pdf $>$.

Pravilnik o djelokrugu i načinu rada Povjerenstva za profesionalne športske klubove, NN II/o7. Zagreb: Narodne novine.

Pravilnik o načinu i rokovima podnošenja akata Povjerenstvu za profesionalne športske klubove, NN II/O7. Zagreb: Narodne novine.

Pravilnik o Registru profesionalnih športskih klubova, NN II/o7. Zagreb: Narodne novine. 
Registar udruga. Available at: 〈http://www.appluprava.hr/RegistarUdruga/〉.

Rudd, J. Marcus, 20I2. The Impact Governance and Club Ppucture has on a Team's Spending Power: A Case Study on the German Bundesliga. Economics Theses. Paper 86. Available at: 〈http://soundideas.pugetsound.edu/economics_theses/86〉.

Stapić, S., 20I2. Nogometni ples milijuna, a u proračunu ni lipe. Slobodna dalmacija, 23. 7. 20I2. Available at: $\quad\langle$ http://www.mfin.hr/hr/novosti/transferi-nogometas-a-nk-dinama-u-strane-nogometnekluboveo6-08-2007>.

Vuković, A., 20II. Stečajni plan kao treći model za športske klubove“. Zbornik radova Pravnog fakulteta u Splitu, 48(4), pp. 63-934.

Zakon o porezu na dobit, NN 177/O4, 90/O5, 57/o6, I46/o8, 80/IO, 22/I2. Zagreb: Narodne novine.

Zakon o porezu na dodanu vrijednost, NN 47/95, I06/96, I64/98, I05/99, 54/oo, 73/oo, 48/o4, 82/04, 90/O5, 76/O7, 87/o9, 94/o9, 22/12, I36/I2. Zagreb: Narodne novine.

Zakon o porezu na dohodak, NN I77/O4, 73/O8, 8O/IO, II4/II, 22/I2, I44/I2. Zagreb: Narodne novine.

Zakon o sportu, NN 7I/O6, 50/o8, I24/IO, I24/II, 86/I2. Zagreb: Narodne novine.

Zakon o udrugama, NN 88/OI, II/O2. Zagreb: Narodne novine. 